\title{
KREASI KOLASE \\ Find, Collect, and Fun Together
}

\author{
Dita Destiana ${ }^{1}$
}

\begin{abstract}
ABSTRAK
Tujuan penulisan makalah ini adalah sebagai salah satu sarana bacaan yang dapat menambah pemahaman dan keterampilan guru, khususnya guru PAUD dan SD. Bagi seorang pengajar perlu mengetahui berbagai karakteristik media pembelajaran. Media merupakan sebuah sarana yang dapat digunakan untuk memfasilitasi aktifitas belajar, di mana media dapat diartikan sebagai perantara yang menghubungkan antara guru dengan siswa. Guru sebagai pengajar hendaknya mampu memilih media yang tepat dalam proses pembelajaran. Media dapat mempengaruhi sikap, nilai emosi, dan mampu mengaktifkan siswa karena disertai dengan kegiatan pembelajaran, dan juga dapat membantu menggabungkan pengalaman belajar yang baru dengan yang sebelumnya. Media pembelajaran adalah alat komunikasi dalam proses pembelajaran antara pengajar dan siswa. Media pembelajaran adalah semacam alat bantu dalam proses pembelajaran, baik di kelas maupun di luar kelas. Adapun manfaat dari penggunaan suatu media pembelajaran dalam proses pembelajaran dapat membangkitkan motivasi dan rangsangan kegiatan belajar dan bahkan membawa pengaruh-pengaruh psikologi terhadap siswa. Pengetahuan dan keterampilan seni rupa bagi guru PAUD/TK dan SD perlu ditingkatkan demi menunjang profesionalisme. Diantara beragam pengetahuan dan keterampilan seni rupa tersebut terdapat seni kolase. Sebenarnya seni kolase merupakan jenis karya seni rupa yang sering menjadi bagian dari proses kreasi guru. Namun kenyataannya, materi tersebut masih perlu dikembangkan sehingga pemahaman secara teoritis, apresiatif dan keterampilan dalam seni ini akan semakin meningkat.
\end{abstract}

\section{Kata Kunci: Media Visual, Keterampilan Seni Rupa, Kreasi Kolase}

\section{A. PENDAHULUAN}

Kemajuan dan peran teknologi sudah sedemikian menonjol, sehingga penggunaan alat-alat, perlengkapan pendidikan dan pengajaran di sekolah-sekolah mulai desesuaikan dengan kemajuan. Penggunaan alat-alat bantu mengajar, alat-alat bantu peraga pendidikan, audio visual, audio-visual serta perlengkapan sekolah serta perlengkapan kerja lainnya, disesuaikan dengan perkembangan tersebut.

Guru memegang peranan yang sangat penting dalam pendidikan, karena itu harus memiliki kualifikasi professional agar mampu mengemban tugas dan perananya (Hamalik, 2008: 11). Guru merupakan ujung tombak yang berhubungan langsung dengan subjek dan objek belajar. Dengan demikian kompetensi dan profesionalisme guru perlu terus ditingkatkan (Sanjaya dalam Muharrar, 2013). Guru

\footnotetext{
1 Mahasiswa Sekolah Pascasarjana UPI
} 
yang professional juga senantiasa berusaha meningkatkan kualitasnya (Sagala, 2011: $14)$.

Profesionalisme keguruan adalah kemampuan guru untuk melakukan tugas pokoknya sebagai pendidik dan pengajar. Pekerjaan profesinal guru harus ditunjang oleh penguasaan pengetahuan dan keterampilan yang mendukung. Yang tidak kalah penting adalah melakukan proses belajar mengajar yang menarik bagi anak (Affandi dalam Muharrar, 2013). Disinilah dibutuhkan sarana dan media pembelajaran yang efektif dan inovatif dengan variasi jenisnya (Zaman dalam Muharrar, 2013).

Perlu diingat bahwa dunia anak-anak merupakan awal perkembangan kreativitas, imajinasi dan segala potensi yang mereka miliki (Hurlock dalam Muharrar, 2013). Kegiatan belajar bagi anak yang ditunjang dengan berbagai sarana seperti alat peraga, media, dan berbagai sumber belajar akan bermanfaat bagi percepatan pencapaian hasil perkembangannya melalui pembelajaran.

Media dan sumber belajar di PAUD dan di SD tentunya sangat beragam, baik berupa buku, gambar-gambar, dan sebagainya. Salah satu pekerjaan yang rumit bagi guru, khususnya guru-guru PAUD dan SD adalah membuat sendiri berbagai macam media belajar yang dapat merangsang daya tarik, kretivitas, dan motivasi anak-anak (Hamalik, 1990) dan kemampuan untuk membuat media pembelajaran ini tidak lepas dari keterampilan guru dalam berkarya seni rupa.

Pengetahuan dan keterampilan seni rupa bagi guru PAUD dan SD perlu ditingkatkan demi menunjang profesionalisme. Diantara beragam pengetahuan dan keterampilan seni rupa tersebut terdapat seni kolase. Sebenarnya seni kolase merupakan jenis karya seni rupa yang sering menjadi bagian dari proses kreasi guru. Namun kenyataannya, materi tersebut masih perlu dikembangkan sehingga pemahaman secara teoritis, apresiatif dan keterampilan dalam seni ini akan semakin meningkat. Selain itu, keterampilan kreasi, baik kolase sangat diperlukan guru mengingat selain menjadi kebutuhan dalam pembelajaran, kegiatan tersebut sering kali juga menjadi kegiatan yang dikompetisikan bagi guru-guru, sehingga diperlukan pemahaman yang kebih jauh.

Merujuk dari pengalaman ini, penulis memandang perlu menyusun sebuah makalah berjudul "Kreasi Kolase (Find, Collage and Fun Together)" yang diharapkan bisa bermanfaat bagi para guru khususnya guru PAU dan SD atau bahkan pihak lain.

Tujuan penulisan makalah ini adalah sebagai suatu sarana bacaan yang dapat ikut menambah pemahaman dan keterampilan guru, khusunya guru PAUD/TK dan SD. Namun secara khusus tujuan makalah ini adalah:

1. Menambah pengetahuan tentang ragam media pembelajaran

2. Menyajikan materi konseptual singkat tentang seni kolase.

3. Menyajikan uraian singkat tentang fungsi, jenis, media, teknik, serta berbagai contoh karya kolase.

4. Menyajikan penjelasan singkat tentang kemungkinan pembelajaran membuat kolase sederhana bagi anak. 


\section{B. PEMBAHASAN}

\section{Konsep Media Pembelajaran}

Media adalah sebuah alat yang mempunyai fungsi menyampaikan pesan (Bovee,1997). Media pembelajaran adalah sebuah alat yang berfungsi dan dapat digunakan untuk menyampaikan pesan pembelajaran. Pembelajaran adalah proses komunikasi antara pelajar, pengajar, dan bahan ajar. Maka dapat dikatakan bahwa, bentuk komunikasi tidak akan berjalan tanpa bantuan sarana untuk menyampaikan pesan. Bentuk-bentuk stimulus dapat dipergunakan sebagai media, diantaranya adalah hubungan atau interaksi manusia, realitas, gambar bergerak atau tidak, tulisan dan suara yang direkam. Dengan kelima stimulus ini akan membantu siswa mempelajari bahan pelajaran atau dapat disimpulkan bahwa bentuk-bentuk stimulus dapat dipergunakan sebagai media adalah suara, lihat, dan gerak.

Banyak batasan atau pengertian yang dikemukakan para ahli tentang media,diantaranya adalah: Asosiasi Teknologi dan Komunikasi (Association of Education and Comunication Technology) (AECT) di Amerika, membatasi media sebagai segala bentuk dan saluran yang digunakan orang untuk menyalurkan pesan atau informasi. National Education Assiciation (NEA), mengatakan bahwa media adalah bentuk-bentuk komunikasi baik cetak maupun audiovisual serta peralatannya. Gagne (1970) mengatakan bahwa media adalah berbagai jenis komponen atau sumber belajar dalam lingkungan siswayang dapat merangsang siswauntuk belajar. Yusuf Hadi Miarso dalam Sanaky (2013) mengatakan bahwa media adalah segala sesuatu yang dapat digunakan untuk merangsang pikiran, perasaan, perhatian, dan kemauan siswa sehingga dapat mendorong terjadinya proses belajar pada diri pembelajar. Secara umum dapat dikatakan bahwa media adalah sarana atau alat bantu yang dapat digunakan dalam proses pembelajaran.

Dari pengertian di atas, dapat disimpulkan bahwa media pembelajaran adalah sarana atau alat bantu pendidikan yang dapat digunakan sebagai perantara dalam proses pembelajaran untuk meningkatkan efektivitas dan efisiensi dalam mencapai tujuan pembelajaran. Dalam pengertian yang lebih luas, media pembelajaran adalah alat, metode dan teknik yang digunakan dalam rangka lebih mengefektifkan komunikasi dan interaksi antara pengajar dan siswa dalam proses pembelajaran di kelas.

Tujuan media pembelajaran sebagai alat bantu pembelajaran untuk:

a. Mempermudah proses pembelajaran di kelas

b. Meningkatkan efisiensi proses pembelajaran

c. Menjaga relevansi antara materi pelajaran dengan tujuan pembelajaran

d. Membantu konsentrasi siswa dalam proses pembelajaran

Manfaat media pembelajaran baik secara umum maupun khusus sebagai alat bantu pembelajaran bagi pengajar dan siswa. Jadi manfaat media pembelajaran adalah sebagai berikut:

a. Pengajaran lebih menarik perhatian siswa sehingga dapat menumbuhkan motivasi belajar

b. Bahan pembelajaran akan lebih jelas maknanya sehingga dapat lebih dipahami siswa, serta memungkinkan siswa menguasai tujuan pembelajaran dengan baik 
c. Metode pembelajaran bervariasi, tidak semata-mata hanya komunikasi verbal melalui penuturan kata-kata lisan pengajar, siswa tidak bosan dan pengajar tidak kehabisan tenaga

d. Siswa lebih banyak melakukan kegiatan belajar sebab tidak hanya mendengarkan penjelasan dari pengajar saja, tetapi juga aktivitas lain yang dilakukan seperti: mengamati, melakukan, mendemonstrasikan, dan lain lain (Sanaky, 2013: 5) berikut:

Selain itu, manfaat media pembelajaran bagi pengajar dan siswa sebagai

a. Manfaat media pembelajaran bagi pengajar, sebagai berikut:

1) Memberikan pedoman, arah untuk mencapai tujuan pembelajaran

2) Menjelaskan struktur dan urutan pengajar secara baik

3) Memudahkan kendali pengajar terhadap materi pelajaran

4) Memberikan kerangka sistematis mengajar secara baik

5) Meningkatkan kualitas pembelajaran

6) Memberikan dan meningkatkan variasi belajar

7) Menyajikan inti informasi, pokok-pokok secara sistematik, sehingga memudahkan penyampaian, dan

8) Menciptakan kondisi dan situasi belajar yang menyenangkan dan tanpa tekanan

b. Manfaat media pembelajaran bagi siswa, sebagai berikut:

1) Meningkatkan motivasi belajar siswa.

2) Memberikan dan meningkatkan variasi belajar bagi siswa.

3) Memudahkan siswa untuk belajar.

4) Merangsang siswa untuk berfikir dan beranalisis.

5) Siswa dalam kondisi dan situasi belajar menyenangkan dan tanpa tekanan.

6) Siswa dapat memahami pelajaran secara sistematis yang disajikan.

\section{Media Visual}

Pada mulanya pada proses pembelajaran hanya menggunakan pendekatan verbal, yakni membaca dan menulis. Baru pada pertengahan tahun 1990-an mulai muncul konsep keterbacaan visual, dalam bentuk grafik seperti sketsa, gambar, foto, diagram, table, dan lain-lain. Dalam buku-buku pelajaran mulai ditampilkan pesanpesan visual melalui berbagai ilustrasi untuk memperjelas keterbacaan visual. Lebih dari itu, pesan-pesan visual disajikan pula dalam berbagai media massa seperti televisi, percetakan, dan produksi. Pesan-pesan visual sangat efektif dalam memperjelas informasi, bahkan lebih jauh lagi dapat mempengaruhi sikap seseorang, membentuk opini masyarakat dan lain-lain.

Pada beberapa penelitian, hasilnya menunjukkan bahwa "pengejar akan lebih efektif apabila objek dan kejadian yang menjadi bahan pengajaran dapat divisualisasikan secara realistic menyerupai keadaan sebenarnya, namun tidak berrti bahwa media harus selalu mempunyai keadaan yang sebenarnya. Sebagai contoh adalah model. Artinya, sekalian model merupakan gambaran nyata dari objek dalam bentuk tiga dimensi tidak dapat dikatakan realistik sepenuhnya. Namun demikian, model sebagai media pembelajaran dapat memberi makna terhadap isi pesan dari keadaan sebenarnya. 
Dari penjelasan di atas, tampaknya perlu mempelajari "pesan visual sebagai media dalam artian hubungannya dengan proses pembelajaran. Bagaimana pengajar dan siswa memanfaatkan pesan visual untuk mempertinggi proses pembelajaran. Sebab keterampilan "memahami pesan visual" dapat diartikan sebagai kemampuan menerima dan menyampaikan pesan-pesan visual tersebut.

Kemampuan menerima pesan visual mencakup kemampuan "membaca kesan visual" secara tepat, memahami makna yang terkandung di dalamnya, menghubungkan unsur-unsur isi kesan visual dengan kesan verbal atau sebaliknya, serta mampu menghayati nilai keindahan visualisasi tersebut. Sedangkan kemampuan menyampaikan kesan visual adalah mencakup menvisualisasikan pesan verbal, melukiskan atau menvisualisasikan makna isi pesan dan menyederhanakan makna dalam bentuk visualisasi (Nana Sudjana, 2009).

\section{Konsep Kreasi Kolase}

Agar dapat memahami tentang seni kolase, terlebih dahulu kita perlu mengetahui apa sebenarnya arti kolase. Kata kolase yang dalam bahasa Inggris disebut 'collage' berasal dari kata 'coller' dalam bahasa Prancis, yang berarti 'merekat'. Selanjutnya kolase dipahami sebagai sebuah seni menempel berbagai macam materi selain cat, seperti kertas, kain, kaca, logam dan lain sebagainya, atau dikombinasikan dengan penggunaan cat atau teknik lainnya (Susanto, 2002: 63).

Kolase adalah sebuah teknik menempel berbagai macam unsur ke dalam satu frame sehingga menghasilkan karya seni yang baru. Dengan demikian, kolase adalah karya seni rupa yang dibuat dengan cara menempelkan bahan apa saja ke dalam satu komposisi yang serasi sehingga menjadi satu kesatuan karya. Kata kunci yang menjadi esensi dari kolase adalah "menempel atau merekatkan" bahan apa saja yang serasi. Karya kolase bias berwujud sebuah karya utuh atau hanya merupakan bagian dari sebuah karya, misalnya lukisan yang menambahkan unsur tempelan sebagai elemen estetis.

Karya kolase dapat dibedakan menjadi beberapa segi, yaitu segi fungsi, matra, corak, dan material.

\section{a. Menurut Fungsi}

Dari segi fungsi, kolase dapat dikelompokkan menjadi dua, yaitu seni murni (fine art) dan seni pakai/terapan (applied art). Seni murni adalah sutu karya seni yang dibuat semata-mata untuk memenuhi kebutuhan artistik. Orang bias menciptakan karya seni murni, umumnya untuk mengekspresikan cita rasa estetik. Dan kebebasan berekspresi dalam seni murni sangat diutamakan (Soedarso, 2006: 101). Fungsi kolase sebagai karya seni murni, semata, untuk ditampilkan keindahan atau nilai estetisnya tanpa ada pertimbangan fungsi praktis. Karya ini mungkin hanya digunakan sebagai pejangan pada dinding atau penghias dalam ruangan. Sedangkan, seni terapan atau seni pakai (applied art) adalah karya seni rupa yang dibuat untuk memenuhi kebutuhan praktis. Kolase sebagai seni terapan berarti dibuat pada benda pakai yang mempunyai fungsi praktis.

Aplikasi kolase sebagai seni terapan umumnya lebih menampilkan komposisi dengan kualitas artistic yang bersifat dekoratif. Sedangkan aplikasi kolase yang lebih 
bebas, sebagai seni murni, tampak lebihberani dalam mengeksplorasi ide-ide kreatif, bahan, dan teknik untuk menghasilkan karya kolase yang unik.

\section{b. Menurut Matra}

Berdasarkan matra, jenis kolase dapat dibagi dua, yaitu kolase pada permukaan bidang dua dimensi (dwimatra) dan kolase pada permukaan bidang tiga dimensi (Trimatra). Karya kolase untuk menghias kendi merupakan kolase pada permukaan bidang tiga dimensi. Sedangkan karya kolase pada permukaan datar untuk membuat hiasan dinding, misalnya dengan biji-bijian atau potongan perca, tergolong kolase dua dimensi.

\section{c. Menurut Corak}

Berdasarkan coraknya, wujud kolase dapat dibagi menjadi dua jenis, yaitu representatif dan nonrepresentatif. Representatif artinya menggambarkan wujud nyata bentuknya masih bias dikenali. Sedangakan nonpresentatif artinya dibuat tanpa menampilkan komposisi unsur visual yang indah.

\section{d. Menurut Material}

Material atau bahan apa pun dapat dimanfaatkan dalam pembuatan kolase asalkan ditata menjadi komposisi yang menarik atau unik. Berbagai material kolase tersebut akan direkatkan pada beragam jenis permukaan, seperti kayu, plastic, kertas, kaca, keramik,gerabah, karton, dan sebagainya asalkan relative rata atau memungkinkan untuk ditempeli.

Secara umum, jenis bahan baku kolase dapat dikelompokkan menjadi dua,yaitu bahan-bahan alam (daun, ranting, bunga kering, kerang, biji-bijian, kulit, batu-batuan dan lain-lain), dan bahan-bahan bekas sintetis (plastic, serat sintetis, logam, kertas bekas, tutp botol, bungkus permen/coklat, kain perca dan lain-lain).

Peralatan dan teknik yang digunakan untuk membuat kolase perlu disesuaikan dengan bahan bakunya, dikarenakan karakter setiap jenis bahan berbeda, jenis peralatan dan teknik yang digunakan untuk membuat kolase berbahan alam berbeda dengan yang digunakan untuk membuat kolase berbahan sintesis. Secara umum, peralatan utama yang dibutuhkan adalah sebagai berikut:

a. Alat potong: gunting, tang, pisau, dan sebagainya.

b. Bahan perekat: lem kertas, perekat vinyl, lem putih, lem plastik, jarum dan benang jahit, serta jenis perekat lainnya (disesuaikan dengan jenis bahan).

Dalam hal teknik, pada umumnya, karya kolase dapat dibuat dengan teknik yang bervariasi, seperti: teknik sobek, teknik gunting, teknik potong, teknik rakit, teknik rekat, teknik jahit, teknik ikat, dan sebagainya. Dan dua atau lebih teknik pun dapat dikombinasikan untuk membuat sebuah karya kolase. Berbagai metode yang digunakan untuk membuat kolase antara lain:
a. Tumpang tindih atau saling tutup (overlapping)
b. Penataan ruang (satial arrangement)
c. Repetisi/pengulangan (repetition)
d. Komposisi/kombinasi beragam jenis tekstur dari berbagai material. 
Berkenaan dengan kolase ada beberapa unsur dasar dan prinsip kolase. Sebagai karya seni rupa, kolase memiliki susunan unsur-unsur dasarvisual. Berbagai unsur rupa yang berbeda karakternya dipadukan dalam suatu komposisi untuk mengekspresikan gagasan artistic atau makna tertentu. Yang dimaksud dengan unsur-unsur rupa adalah aspek-aspek bentuk yang terlihat, kongkret yang dalam kenyataannya saling terkait dan tak mudah dipisahkan satu dengan lainnya. Tampilan keseluruhan menentukan perwujudan dan makna aspek bentuk itu sendiri.

Unsur-unsur rupa (Susanto dalam Muharrar, 2013) yang terdapat pada kolase, antara lain:

a. Titik dan bintik. Titik adalah unit unsur rupa terkecil yang tidak memiliki ukuran panjang dan lebar. Sedangkan bintik adalah titik yang sedikit lebih besar. Unsur titik pada kolase dapat diwujudkan dengan bahan, misalnya, butiran pasir laut. Sedangkan bintik dapat diwujudkan dengan bahan seperti kerikil kecil atau bijibijian yang berukuran kecil dan sejenisnya.

b. Garis. Merupakan perpanjangan dari titik yang memiliki ukuran panjang namun relative tidak memiliki lebar. Ditinjau dari jenisnya, garis dapat dibedakan menjadi garis lurus, garis lengkung, garis putus-putus, dan garis spiral. Unsur garis pada kolase dapat diwuujdkan dengan potongan kawat, lidi, batang korek, benang, dan sebagainya. Garis dapat pula terbentuk dari batas warna yang berdempetan.

c. Bidang adalah area yang merupakan unsur rupa yang terjadi karena pertemuan beberapa garis dan memiliki dimensi panjang dan lebar. Bidang dapat dibedakan menjadi bidang horizontal, vertical, dan diagonal. Dapat pula dibedakan menjadi bidang geometris dan non geometris. Yang termasuk bidang geometris adalah lingkaran, segitiga, segi empat, elips, setengah lingkaran, dan sebagainya. Bidang geometris memiliki kesan formal sedangkan non geometris bentuknya tidak beraturan, memiliki kesan tidak formal, santai, dan dinamis. Aplikasi unsur bidang pada kolase juga bias berupa bidang datar (dua dimensi) dan bidang bervolume (tiga dimensi).

d. Warna merupakan unsur rupa yang terpenting dan salah satu wujud keindahan yang dapat diceap oleh indra penglihatan manusia. Warna secara nyata dapat dibedakan menjadi warna primer, sekunder, dan tensier. Unsur warna pada kolase dapat diwujudkan dari unsur cat, pita/renda, kertas warna, kain warnawarni dan sebagainya.

e. Bentuk dapat diartikan bangun, rupa, wujud. Bentuk dalam pengertian dua dimensi akan berupa gambar yang tak bervolume, sedang dalam pengertian tiga dimensi memiliki ruang dan volume. Bentuk juga bias dibagi menjadi bentuk geometris dan non-geometris.

f. Gelap-terang adalah tingkatan value yang bias terjadi antara hitam dan putih atau antara warna gelap dan warna terang. Dalam membuat karya kolase, unsur visual gelap-terang sangat penting untuk memberikan penonjolan pada unsur tertentu atau untuk memberikan penonjolan pada unsur tertentu atau untuk memberikan kesan jauh-dekat, dan kesan volume atau gempal. 
g. Tekstur merupakan nilai, sifat, atau karakter dari permukaan suatu benda, seperti halus, kasar, bergelombang, lembut, lunak, keras, dan sebagainya. Tekstur secara visual, dapat dibedakan menjadi tekstur nta (terlihat kasar, diraba kasar) dan tekstur semu (dilihat kasar, diraba halus). Unsur tekstur nyata pada kolase pada kolase dapat berupa kapas, karung goni, kain sutra, amplas, sabut kelapa, karet busa, dan lain-lain. Sedangkan tekstur semu dapt berupa hasil cetakan irisan belimbing, tekstur koin di kertas, dan sebagainya.

Prinsip rancangan penting diperhatikan dalam menata komposisi suatu kolase, karena keindahan atau keunikan struktur dan keutuhan maknanya ditentukan oleh ketepatan dalam mengolah beragam unsur rupa sesuai prinsip ranjangan. Beberapa prinsip rancangan. Beberapa prinsip dasr diaplikasikan pada kolase, antara lain:

a. Irama. Pengulangan unsur-unsur rupa yang diatur sedemikian rupa. Jenis pengulangan antara lain: pengulangan sejenis (repetitive), pengulangan alternatif, dan pengulangan progesif.

b. Keseimbangan. Kesamaan bobot dari berbagai unsur rupa yang dipadukan mungkin tidak sama namun nilai bobotnya seimbang. Keseimbangan ada beberapa jenis, antara lain: keseimbangan sentral/terpusat, keseimbangan diagonal,simetris, dan keseimbangan asimetris.

c. Kesatuan. Susunan unsur-unsur rupa yang saling bertautan dan membentuk komposisi yang harmoni dan utuh, sehingga tidak ada bagian yang berdiri sendiri. Untuk menciptakan kesatuan, unsur rupa yang digunakan tidak harus seragam, tetapi dapat bervariasi dalam bentuk, warna, tekstur, dan bahan.

d. Pusat Perhatian. Unsur yang sangat menonjol, atau berbeda dengan unsur-unsur yang ada disekitarnya. Untuk menciptakan pusat perhatian dalam kolase, kita dapat menempatkan unsur yang paling dominan atau kontras di sekitar unsur lainnya dengan cara memberikan perbedaan dari segi tekstur bentuk, ukuran, atau pun warna (Supriyono, 2010:87-98).

\section{Contoh Pembelajaran Kreasi Kolase Sederhana Bagi Anak}

Karya kolase sederhana dapat dibuat dari bahan yang ada disekitar kita, baik bahan alam maupun bahan bekas sintetis. Dari bahan-bahan tersebut, dapat dimunculkan ide-ide kreatif yang segar yang bias menghasilkan kreasi-kreasi kolase yang unik dan bermanfaat. Selanjutnya bahan yang sudah tersedia disusun sesuai jenisnya. Kemudian dipotong-potong sesuai ukuran dan bentuk yang diinginkan. Tempelkan bahan-bahan tersebut menurut bentuk dan komposisi yang dikehendaki hingga karya kolase selesai dan bias dinikmati hasilnya.

Untuk mendapatkan hasil kolase yang lebih baik, maka perlu diperhatikan beberapa hal:

a. Usahakan semua bidang tertutup oleh bahan yang ditempelkan (tidak banyak bidang kosong)

b. Perhatikan prinsip-prinsip rancangan dalam menyusun bahan-bahan.

c. Gunakan perekat menurut jenis bahan yang akan ditempel. Untuk merekatkan kertas tipis cukup menggunakan lem kertas, tetapi bila bahan yang direkatkan tebal atau mudah lepas, maka gunakan lem yang lebih kuat yaitu lem putih atau lem alteco. 
d. Gunakan bahan yang agak tebal dan kaku untuk bidang dasar yang akan ditempel, misalnya kertas korton, duplex, triples, atau bahan lain yang sejenis.

Karya kolase yang kurang memaksimalkan pemanfaatan bidang yang tersedia, yaitu tidak semua bidang diiisi tempelan, terkesan belum selasai dan terlalu sederhana. Oleh karena itu, untuk menghasilkan karya kolase yang baik usahakan semua bidang yang tersedia diisi tempelan secara optimal dengan mempertimbangkan prinsip-prinsip rancangan.

Pembelajaran kolase bagi anak, khususnya PAUD/TK atau SD, tentunya perlu dilakukan dengan memperhatikan beberapa hal:

a. Gunakan alat pemotong yang mudah digunakan, misalnya gunting. Namun sebaiknya guru mendampingi saat anak memotong, atau mungkin guru membantu memotongkan bahan yang disediakan.

b. Bahan yang disediakan sebaiknya mudah dipotong sehingga tidak menyulitkan anak. Misalnya, daun kering, kertas, karton bekas, dan lain-lain.

c. Bidang dasar kolase menggunakan kertas tebal, karton atau kertas duplex yang tidak terlalu besar sehingga anak tidak kesulitan untuk menempel bidang tersebut secara keseluruhan.

d. Teknik boleh dipadukan antara gambaran tangan dan tempelan atau kolase. Misalnya anak menggambar kepala untuk figure manusia, mungkin tentang dirinya atau ibunya atau temannya. Selanjutnya bagian lain (baju, celana, rok, dll.) dibuat dengan teknik kolase.

\section{PENUTUP}

Pembelajaran di PAUD dan SD membutuhkan sebuah keterampilan khusus yang terencana dengan baik, dengan tujuan yang sesuai pada tahap perkembangannya serta produktif merupakan bagian yang sangat penting dari lingkungan sebuah taman kanak-kanak.

Media pembalajaran sangat berperan penting dalam pembelajaran di taman kanak-kanak, karena anak-anak membutuhkan banyak hal yang menarik untuk disentuh, dicicipi, didengar, dilihat dan dicium. Media yang baik bagi mereka adalah media yang kaya untuk merangsang atau meningkatkan segenap kemampuan dasar yang harus mereka kembangkan, sesuai dengan potensi yang dimiliki mereka.

Kolase adalah sebuah teknik menempel berbagai macam unsur ke dalam satu frame sehingga menghasilkan karya seni yang baru. Dengan demikian, kolase adalah karya seni rupa yang dibuat dengan cara menempelkan bahan apa saja ke dalam satu komposisi yang serasi sehingga menjadi satu kesatuan karya.

Karya kolase sederhana dapat dibuat dari bahan yang ada disekitar anak, baik bahan alam maupun bahan bekas sintetis. Dari bahan-bahan tersebut, dapat dimunculkan ide-ide kreatif yang segar yang bisa menghasilkan kreasi-kreasi kolase yang unik dan bermanfaat khususnya bagi anak.

\section{DAFTAR PUSTAKA}

Asmawati, Luluk. 2014. Perencanaan. Pembelajaran Paud. Serang:

Hamalik, Oemar. 2008. Pendidikan Guru Berdasarkan Pendekatan Kompetensi. Jakarta: Bumi Aksara. 
Muharrar, Syakir dan Verayanti, Sri. 2013. Kreasi Kolase, Montase, Mozaik Sederhana. Semarang: Esensi Erlangga Grup

Nana, Sudjana dan Rivai, Ahmad. 2009. Media Pengajaran. Bandung: Sinar Baru Algesindo.

Sagala, Syaiful. 2011. Kemampuan Profesional Guru dan Tenaga Kependidikan. Bandung: Alfabeta

Sanaky, Hujair. 2013. Media Pembelajaran Interaktif-Inovatif. Yogjakarta: Kaukaba. 